DOI: 10.20472/TEC.2018.006.003

TSOGHIK GRIGORYAN

Higher Colleges of Technology, United Arab Emirates

\title{
TEACHERS' REFLECTIVE JOURNAL ANALYSIS OF IPAD BASED LANGUAGE LEARNING THROUGH THE ACTIVITY THEORY FRAMEWORK
}

\begin{abstract}
:
This is an experimental study of an iPad based language learning in the United Arab Emirates (UAE) context. A tertiary level college in the UAE went paperless in 2012 and implemented iPads for its Foundations Program, eliminating paper and pen teaching-learning methods from the classroom. The innovation brought up challenges in the technical and methodological fields, as well as in language learning ways, skills and practices. The aim of this study was to find the emerging themes of the teachers' reflective journals in the evaluation of their lessons and diagnosis of problems throughout the two-phase experiment. The data sources that informed this study were: soft copies of four teachers' weekly written reflections in phase one, which lasted for four weeks, and soft copies of two teachers' weekly written reflections in phase two which lasted for another four weeks. So, four teachers teaching four groups for four weeks wrote sixteen journals in phase one, and two teachers teaching two groups for another four weeks wrote eight journals in phase two. By the end of the experiment the teachers produced twenty-four reflective journals, which this study looked at through the Activity Theory framework. The results showed that today's "digital natives", who were elementary level Emirati language learners, demonstrated a strong preference and motivation for using iPads for their everyday language learning.
\end{abstract}

\section{Keywords:}

Paperless learning, iPad, reflective journals, EFL, Activity Theory 


\section{Introduction}

The digital enhancement of people's cognition supported by mobile technologies and digital tools is a reality in every profession and every field today. However, it should not be assumed that the human brain is no longer significant and that mobile technology is smarter by itself. Quite the opposite, "It is through the interaction of the human mind and digital technology that the digitally wise person is coming to be" (Thomas 2011, p. 27). The time we live in necessitates the urge to educate digitally smart students and teachers, to embrace digital enhancement in the field of education and encourage others to do so. "With our eyes wide open to enhancement's potential harm as well as its benefits, let us bring our colleagues, students, teachers, parents, and peers to the digital wisdom of the twentyfirst century" (p. 27).

Prensky (2012) has identified today's generational change that leads to a really big discontinuity, which one can call 'singularity' _ an event that changes things so fundamentally that there is no way back. He has used the term "Digital Natives" and argued that the new generation are different from the previous generations because of the technological changes. Therefore, it will be easier and more productive to meet today's "Digital Native" students in their comfort zone and use the digital technology in teaching to achieve significant progress. As Solomon and Schrum (2007) state, "The competition will be fierce and can come from anywhere in this flat world. In some ways, students today are ahead of their elders. Technology is second nature to them and they accept and use it without question. Schools lag behind" (p. 17). The urge for educators to accept the needs of this generation differently has become even more crucial. The educational systems try to implement new innovative projects and take new initiatives without excluding the outdated practices, which prevents the educational system from embracing the future and meeting the demands of the new generation. A tertiary level institution in the UAE tried to embrace digital enhancement in the field of language learning and went paperless by eliminating traditional paper and pen methods from the classroom and implementing iPads for its Foundations Program. The innovation brought up enormous challenges in language learning ways, skills and practices. Therefore, research and investigation were needed to shed light on pros and cons of various aspects of that innovative change. This study aims at exploring the results of using mobile technology educationally by looking into teacher and learner practices toward using iPads in language learning. The framework of this study is the Activity Theory and the research question guiding it is the following:

What are the emerging themes of the teachers' reflective journals in the evaluation of their lessons and diagnosis of problems? 


\section{Literature Review}

Theories and approaches related to innovation adoption include but are not limited to Diffusion of Innovation Theory (Rogers 2003), Theory of Reasoned Action (Fishbein and Ajzen 2010), Enhanced Technology Acceptance Model (Venkatesh and Davis 2000), Unified Theory of Acceptance and Use of Technology (Venkatesh and Davis 2000), Social Cognitive Theory (Bandura 1999) and Activity Theory (Engestrom 1999). Many other approaches have emerged and have been developed from the above mentioned models and theories to conduct research into technology-use. In turn they have been practiced in various spheres of life, as well as in education.

Though ICT adoption is a well-researched area of study in IT research, its application to education is still under investigation (Churchill and Wang 2014; Lai, Meder and Wegner 2015). Some educational institutions today insist on integrating mobile devices without determining their benefits and possible negative effects on students' education. Funding, innovative ways of management, ecological problems, modern pedagogies, and other factors are all mentioned as hurdles for ICT adoption, yet the area lacks research and consensus (Meder and Wegner 2015).

One of the approaches to the adoption of innovation that educational technologists will benefit greater understanding and awareness from is the diffusion of innovation theory. Diffusion of innovation theory explains how an idea or a product gains an impetus over time and diffuses through a specific population (Boczkowski 2010). It aims to study people's technology adoption in terms of time, innovation, communication methods and the social system. This means that people adopt an innovative product or a new idea and perceive it as new or innovative. Ghezzi, Rangone and Balocco (2013) claim that diffusion theory should be revisited to identify external determinants that enable or hinder evaluation of the new technology prior to the technological activation phase in education. The model they propose addresses regulation, environment, strategy and technology (REST), which are the four determinants stimulating technology activation.

Another theory that believes that the behavioural target is shaped by the individual's attitudes and subjective norms is the Theory of Reasoned Action (TRA). It was developed to describe the connection of individuals' behaviours and attitudes within their actions. "The aim of the TRA is to investigate the relationship between attitude and behaviour based on two major concepts: principles of compatibility and behavioural intention. With this characteristic, the TRA is a predictive model and, therefore, is used in a variety of fields, such as banking, public, education, and industries to predict individuals' actions based on certain criteria" (Mishra, Akman and Mishra 2014, p. 30). The attitude and subjective norm are the central factors of individuals' objectives of implementing ICTs and were found to have a big impact on adopting ICT (Mishra, Akman and Mishra 2014; Doane, Pearson and Kelley, 2014). Several studies found that subjective norm affects individual's behavioural intention (Cooke and French 2008; Doane, Pearson and Kelley 2014), satisfaction, 
information sharing (Tsai, Chen and Chien 2012), and perceived usefulness (Venkatesh and Davis 2000).

The enhanced Technology Acceptance Model (TAM) suggests that perceived ease of use and perceived usefulness are direct channels of technology acceptance behaviours. As Gong, Xu and Yu (2004) define, "Perceived usefulness is defined as the prospective user's subjective probability that using a specific application system would increase his or her job performance within an organizational context" (p.366). Perceived ease of use, on the other hand, "refers to the degree to which the prospective user expects the target system to be free of effort" (p. 366). Several studies have used Enhanced Technology Acceptance Model as their theoretical background for explaining technology use and adoption (Cheung and Vogel 2013; Gong, Xu and Yu 2004; Teo 2009) and found that perceived usefulness influences attitudes and satisfaction toward technology use (Limayem, Hirt and Cheung 2007; Venkatesh and Davis 2000).

The Unified Theory of Acceptance and Use of Technology (UTAUT) looks at how two factors: intention and behaviour, progress over time and are moderated by gender, age and experience (Venkatesh and Davis 2000). The determinants of intention are supposed to be the performance expectancy, effort expectancy, and social influence, whereas, the determinants of behaviour are supposed to be the intention and facilitating conditions (Venkatesh and Davis 2000).

Social Cognitive Theory (SCT) describes how the individual obtains and sustains a specific behaviour based on learning from others (Bandura 1999). This theory suggests that the acquisition of knowledge is related to observing others within the context of social interactions. It also explains that a specific behaviour can be influenced by final expectations and self-efficacy, while final expectations and self-efficacy can be affected by prior behaviour. Several studies have used SCT and found significant relationships with other concepts in ICT adoption and use, such as that self-efficacy can positively influence perceived ease of use and perceived usefulness (Chiu, Hsu and Wang 2006; Swearer, Wang, Berry and Myers 2014; Bandura 2002).

Activity Theory (AT), as propounded in Soviet psychology, is the umbrella term for several eclectic social sciences theories. It is not a predictive theory, but more of a descriptive framework, which studies the whole activity system beyond one user. It is a crossdisciplinary framework for studying how humans purposefully transform natural and social reality, including themselves, as an ongoing culturally and historically situated, materially and socially mediated process" (Roth, Radford and Lacroix 2012, p. 1). Entrenched in the dialectal psychology, it transcends traditional dichotomies of macro and micro, thought and action, intervention and observation, qualitative and quantitative by integrating three perspectives: the objective, the ecological and the sociocultural (Engestrom 1999). 


\section{Theoretical Framework}

The theoretical framework guiding this study is the Activity Theory (AT). AT was founded by Soviet psychologists Vygotsky, Lurija, Rubinstein and Leontev in the 1930s. Their idea was that activity was a fundamental philosophical and psychological concept because it was the essential notion in any viable philosophical anthropology. Hence, the statement that humans were active creatures was not to be simply registered as an empirical observation. It was never denied by any philosopher that humans act. Yet, it was a statement about the very nature of thought and its behaviour on the world. The Soviet scholar who developed this idea was Vygotsky who initially illustrated it in a form of a basic triangle, which consisted of a subject, an object and an artefact. However, he laid bare what he argued as then a problem in psychological investigation that limited experimental research to reductionist laboratory studies separated from the contexts of human lives (Barab, Evans and Baek 2004).

Vygotsky's theoretical endeavour, later, was linked and elaborated by the Finnish scholar Engestrom, who added societal and contextual dimensions to Vygotsky's model and "[broadened] the process by linking the idea of activity systems to concept of context, stating that contexts are activity systems" (Engestrom 1993 in Esch and John 2004, p. 56). The main concept of this approach is that the individual actions occur in relation to three factors: the available tools, the community and the labour distribution in that community. The subject implements a tool to perform cognitive functions and cannot directly act on the object. The unit of analysis in AT is the concept of object-oriented, collective and culturally mediated human activity system. According to a leading theorist in AT, Nardi (1996), "Activity Theory focuses on practice, which obviates the need to distinguish 'applied' from 'pure' science ... where understanding everyday practice in the real world is the very objective of scientific practice" (p. 45).

It is by amending and extending Vygotsky's and Leontiev's theories in a way this paper sketches that we can argue for the fruitfulness of AT. In this complex task possible debates with other school of thought should be faced and welcomed. Jonassen and Murony (1999 in Liaw and Huang, 2014), explain that, "When analysing human activity we must examine not only the kinds of activity that people engage in, but also who are engaging in that activity, what their goals and intentions are, what objects or products result from the activity, the rules and norms that circumscribe that activity, and the larger community in which the activity occurs" (p. 4).

When iPad is used in language learning, it is not seen as the object of learning the language but as a device to realize the language acquisition process. Thus, based on the technological outlook of AT, individual functioning is considered to be distributed across and situated within the transaction of the contexts of the subject, available tools, and community with the division of labour (Uden 2007 in Liaw and Huang 2014). Since this 
study aimed to conduct an AT based enquiry into iPad implementation for language teaching and learning, it conceptualized a research model to provide insights into learner perceptions of the iPads in an educational setting, which then was analysed using the data from the four teachers' reflective journals. It shows the initial model of the AT based distribution of the tool, subject and object in connection with the control of learning and communication of learning. The experimental phase model was designed in connection with the initial AT model where the tool was the iPad as a means of language learning and subjects were Emirati beginner level EFL learners. In the experimental phase the control of learning was realized through iPad based vs paper based learning, and the communication of learning was realized through iPad and textbook groups which both aimed at developing high language achievement.

\section{Methodology}

\section{Site and Subject Selection}

The site of the study was a governmental tertiary level learning institution in the UAE. The institution provided post-secondary education to $17-25$ year old Emirati women. The institution started the iPad project at the Foundations program and moved from traditional language learning and teaching to paperless methods, which meant teaching and learning was realized solely through iPad applications, online resources and electronic texts. The program supported students needing English language assistance in meeting the admission criteria of the Bachelor degree program prior to their entering their chosen program major. It offered four levels of English proficiency: beginner, pre-intermediate, intermediate and advanced. This experiment concentrated on the beginner level. The beginner level and the Foundations program were chosen for the experiment because this was the program and the level that all students needed to complete first as they entered the institution and this was when they tried iPads for language learning purposes for the first time.

Research participants were 17 to 25 year old Emirati women who, after high school, were placed in higher institutions according to their Common Educational Proficiency Assessment test results (CEPA). CEPA is a set of locally developed standardized tests used for admissions and placement by the federal institutions. The students entered at the CEFR A1 level having CEPA score of 150 and were expected to exit midway through CEFR A2 level CEPA 156 . Out of 250 newly admitted students, 80 were randomly chosen for the experiment. Then, the 80 students were randomly placed in four different groups: two iPad groups and two textbook groups, 20 students in each. The researcher and three other level one teachers were assigned to teach those groups, each teacher teaching one group. The teachers were employed by the institution and were equally experienced and qualified to work with level one students. Though students were called level one or beginner 
level students, they were actually false beginners, since they studied English in secondary and high school. However, for some reason they did not improve their English language proficiency at school and scored low in CEPA-English.

The groups used the following textbooks for the course as mentioned in the Common Course Outline, which all four teachers followed during the experiment: $Q$ : Skills for Success INTRO: Reading and Writing and Q: Skills for Success INTRO: Listening and Speaking. Textbook groups used the hard copy textbooks and the iPad groups used the ebooks.

\begin{tabular}{|c|c|c|c|}
\hline \multicolumn{4}{|c|}{ FND Level 1 Work Plan 2014 - 2015 Q-Skills Intro } \\
\hline Week & Reading and Writing & Speaking and Listening & \\
\hline 2 & $\begin{array}{l}\text { Unit 1: What kind of person are you? } \\
\text { Reading } 1 \text { : What kind of person are } \\
\text { you? } \\
\text { Reading 2: Cristiano Ronaldo. }\end{array}$ & $\begin{array}{l}\text { Unit 1: What are you interested in? } \\
\text { Listening 1: Are you interested in art? } \\
\text { Listening 2: The life of Liz Alan. }\end{array}$ & $\begin{array}{l}\text { Grammar: } \\
\text { - Simple Present, verb 'to be' } \\
\text { - who, what, where } \\
\text { Writing } \\
\text { - Write about yourself and a friend. } \\
\text { Listening }\end{array}$ \\
\hline 3 & $\begin{array}{l}\text { Unit 2: Who are your friends? } \\
\text { Reading 1: Different kinds of friends. }\end{array}$ & $\begin{array}{l}\text { Unit 2: How do you make friends? } \\
\text { Listening 1: Making friends. } \\
\text { Listening 2: Kate and Sun Hed }\end{array}$ & $\begin{array}{l}\text { - Listen to people talking about } \\
\text { their interests } \\
\text { - Listen to people giving examples } \\
\text { Speaking } \\
\text { - Interview a student about his or } \\
\text { her interests } \\
\text { - Give a presentation on good ways } \\
\text { to make friends and give details } \\
\text { and examples }\end{array}$ \\
\hline 4 & $\begin{array}{l}\text { Unit 3: Do students spend too much } \\
\text { time in school? } \\
\text { Reading 1: Comparing schools in } 3 \\
\text { countries. } \\
\text { Reading 2: Schools in Germany and } \\
\text { around the world }\end{array}$ & $\begin{array}{l}\text { Unit 3: What makes a good school? } \\
\text { Listening 1: Let us take a tour. } \\
\text { Listening 2: Listening for examples. }\end{array}$ & $\begin{array}{l}\text { Grammar } \\
\text { - Adjectives and adverbs. } \\
\text { Writing: Verbs + gerund or infinitive. } \\
\text { - Write about your college } \\
\text { - Describe a special meal or } \\
\text { celebration. }\end{array}$ \\
\hline 5 & $\begin{array}{l}\text { Unit 4: When do we eat special foods? } \\
\text { Reading 1: Celebrating the New Year } \\
\text { with food. } \\
\text { Reading 2: Dictionary entries. }\end{array}$ & $\begin{array}{l}\text { Unit 4: How do you choose your } \\
\text { food? } \\
\text { Listening 1: Lifestyles and Food } \\
\text { Choices. } \\
\text { Listening 2: Listening for reasons. }\end{array}$ & $\begin{array}{l}\text { - Listen to a college campus tour } \\
\text { - fisten to people giving reasons } \\
\text { Speaking choices } \\
\text { - Give a presentation on a plan for a } \\
\text { perfect school or college } \\
\text { - Interview a student about his or } \\
\text { her food choices }\end{array}$ \\
\hline
\end{tabular}

Table 1: The work plan.

All four groups followed the work plan illustrated in Table 1 and covered the same material, although, with different methods of instruction. 


\begin{tabular}{|c|c|c|}
\hline The Treatment Plan & $\begin{array}{l}\text { Classes with iPad } \\
\text { (iPad groups) }\end{array}$ & $\begin{array}{l}\text { Classes without iPad } \\
\text { (Textbook groups) }\end{array}$ \\
\hline Reading: Reading texts & Interactive e-book & Paper book \\
\hline $\begin{array}{l}\text { Reading task completion } \\
\text { (E.g. creating conceptual maps, story } \\
\text { lines, time lines, meaning depiction, } \\
\text { etc.) }\end{array}$ & $\begin{array}{l}\text { Annotation apps, Screen Chomp, } \\
\text { Educreations, Skitch, PuppetPals } \\
\text { HD, DocScan HD, Popplet, etc. }\end{array}$ & Pen, pencil and highlighter \\
\hline $\begin{array}{l}\text { Vocabulary and Spelling } \\
\text { (E.g. working with Oxford } 3000 \text { lists, } \\
\text { practicing vocabulary and spelling) }\end{array}$ & $\begin{array}{l}\text { E-book interactive exercises, } \\
\text { Spelling City, Socrative, My Library, } \\
\text { Vocabulary puzzles, etc. }\end{array}$ & $\begin{array}{l}\text { Textbook exercises, print out } \\
\text { materials }\end{array}$ \\
\hline Writing: Writing scripts & Interactive e-book and Pages & Paper and pen \\
\hline $\begin{array}{l}\text { Writing task completion } \\
\text { (E.g. writing sentences and } \\
\text { paragraphs, completing grammar and } \\
\text { spelling exercises) }\end{array}$ & $\begin{array}{l}\text { Academic writing in English, } \\
\text { Grammar checker, English Spelling } \\
\text { and Punctuation, iAcademic, etc. }\end{array}$ & Paper and pen \\
\hline $\begin{array}{l}\text { Brainstorming and outlining } \\
\text { (E.g.planning ideas, conceptualizing } \\
\text { the plot, outlining the steps) }\end{array}$ & $\begin{array}{l}\text { MindMeister, Brainstorming Canvas, } \\
\text { iMindQ, Project Planning, } \\
\text { Mindomo, etc. }\end{array}$ & Paper and pen \\
\hline Listening: Listening audios & Interactive e-book & Textbook attached CD \\
\hline $\begin{array}{l}\text { Listening task completion } \\
\text { (E.g. listening to dialogues, talks, } \\
\text { watching videos and completing } \\
\text { exercises, taking notes while listening) }\end{array}$ & $\begin{array}{l}\text { Listening Master, Sound Note, Voice } \\
\text { recorder, SoundCloud, Wattpad, etc. }\end{array}$ & CD and book exercises \\
\hline $\begin{array}{l}\text { Spealing: Speaking tasks } \\
\text { (E.g. discussing statements, giving } \\
\text { suggestions, offering help, debating } \\
\text { over a topic, presenting themes) }\end{array}$ & $\begin{array}{l}\text { Oral and virtual discussions, Audio } \\
\text { blogs, Voice messaging, KeyNote } \\
\text { presentations, iMovies, Prezi } \\
\text { presentations, etc. }\end{array}$ & $\begin{array}{l}\text { Oral discussions, debates, } \\
\text { poster presentations }\end{array}$ \\
\hline $\begin{array}{l}\text { Communication } \\
\text { (E.g. sharing information with peers } \\
\text { and teachers, asking and answers } \\
\text { questions concerming the language) }\end{array}$ & $\begin{array}{l}\text { Online and real time student-student } \\
\text { and student-teacher interaction }\end{array}$ & $\begin{array}{l}\text { student-student and student- } \\
\text { teacher interaction }\end{array}$ \\
\hline
\end{tabular}

Table 2: The treatment plan

As illustrated in Table 2, the iPad groups followed the conditions set by the institution and fully used iPads for their language learning with no presence of traditional learning methods: such as paperback texts, stationary or pen-written notes. Instead, they used annotation apps to complete the exercises, presentation apps to create presentations, interactive texts to complete reading and writing tasks and individual audios to complete the listening exercises. In the contrary, the textbook groups did not use iPads for anything and followed the traditional methods of using pen and paper for writing and paperback texts for reading. The experiment lasted for 80 teaching periods, which was followed by the posttest. Each period lasted for 50 minutes. Students had four periods of English every 
day, from Sunday to Thursday. They did not take any other subjects except English throughout level one.

After the first phase of the experiment, the two textbook groups that were not exposed to iPads became iPad groups in phase two and commenced their studies by using iPads for another 80 teaching periods. In this second phase, the groups used annotation apps to complete the e-book exercises, presentation apps to create multimedia presentations, interactive texts to complete reading and writing tasks and individual audios to complete the listening exercises. Another two units were covered from each textbook within 80 periods of English language class. This phase served as a within-method triangulation. The intention here was originally to maximize the validity of research by playing the methods off against each other (Flick 2006).

\section{The instrument}

The qualitative analysis were obtained through weekly reflective journal logs that the four teachers involved in this study kept to record the procedure of the experiment for all four groups during phase one and two of the experiment. The two data sources that informed this part of the study were: soft copies of four teachers' weekly written reflections in phase one, which lasted for four weeks, and soft copies of two teachers' weekly written reflections in phase two which lasted for another four weeks. This means, four teachers teaching four groups for four weeks wrote sixteen journals in phase one, and two teachers teaching two groups for another four weeks wrote eight journals in phase two. By the end of the experiment the teachers produced twenty-four reflective journals.

The descriptive journals were standardized through team meetings and contained information about 80 teaching periods with four groups and another 80 teaching periods with two groups. As Table 3 illustrates, they were divided into three sections. Section one contained information about the work plan; such as, details about the unit, learning outcomes and skills to be taught. In section two, teachers wrote about what they covered within the week. In section three, they reflected on their teaching and students' learning. 


\begin{tabular}{|c|c|c|c|}
\hline $\begin{array}{l}\text { Week } \\
\text { Reading and } \mathrm{V} \\
\text { Speaking and I } \\
\text { Grammar and }\end{array}$ & Unit & Learning Ou & les \\
\hline iPad Group 1 & iPad Group 2 & Textbook Group 1 & Textbook Group 2 \\
\hline Day 1 & Day 1 & Day 1 & Day 1 \\
\hline Day 2 & Day 2 & Day 2 & Day 2 \\
\hline Day 3 & Day 3 & Day 3 & Day 3 \\
\hline Day 4 & Day 4 & Day 4 & Day 4 \\
\hline Day 5 & Day 5 & Day 5 & Day 5 \\
\hline $\begin{array}{l}\text { The teacher's } \\
\text { reflections }\end{array}$ & $\begin{array}{l}\text { The teacher's } \\
\text { reflections }\end{array}$ & $\begin{array}{l}\text { The teacher's } \\
\text { reflections }\end{array}$ & $\begin{array}{l}\text { The teacher's } \\
\text { reflections }\end{array}$ \\
\hline
\end{tabular}

Table 3: Weekly journals

The journal summaries served as registers of parallels to document and reflect on the research experience as well as the advantages and disadvantages of the methods and ways the material was introduced by the teachers and reproduced by the students.

\section{Ethical Considerations}

Experimental research with people carries ethical problems and has a moral dimension because of the control exercised over participants' behaviour. However, while this is selfevident in experimental research, ethical dilemmas lurk in any research involving people (Robson, 2005). To minimize the ethical problems this study followed Bryman and Bell's (2007) principles of ethical considerations.

Neither students nor teachers were harmed in any way during the study. None of the participants complained about any aspect of the experiment being harmful for their life, learning or teaching. All four groups followed the work plan and covered the same material to minimize harm to the learning process. The study was carried out in students' everyday classroom, hence; minimizing the risk of harm to the participants (Yin 2009). The participant students in all four groups were informed about the experiment before it commenced and the procedures were explained to them in details. Their participation was not mandatory or forced and it was their decision to participate in the experiment and sign the consent form, which was introduced to them and discussed in details. This study kept the confidentiality of its participants. A contact letter of invitation was given to the participants assuring them that their anonymity would be protected indefinitely. The demographic data did not contain participants' names or the class records and remained anonymous to all but the researcher. Ethical standards in the reposting of the data was guaranteed by strictly following Robson's (2005) Reporting Fixed Design Research guidelines (pp. 503-504). 


\section{Results}

In this study the Activity Theory of using two methods for language learning: iPad based and textbook based language learning, starts out from the idea that students start using the methods in the context of their participation in language learning activities. Language learning in this view is a mode of activity that can be characterized by specifying the method that describes how the activity in general is accomplished. To describe this accomplishment, two conceptual models of activity theory have been formed based on two methods: iPad based and textbook based language learning (Figure 1).

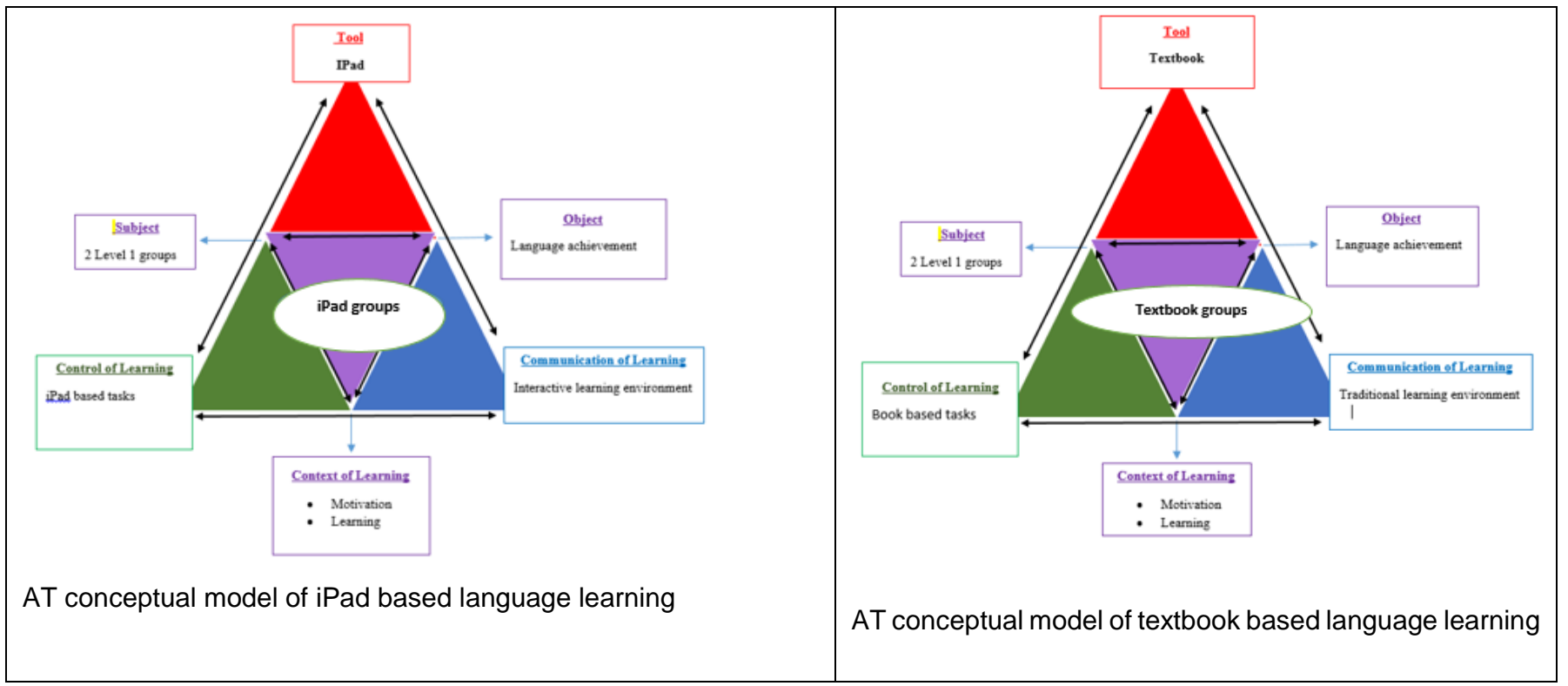

Figure 1: AT conceptual models of two methods

The models look at the activity as a purposeful, productive process carried out by subjects, who are 80 beginner level language learners placed in four homogeneous groups, on an object, which is language achievement, via two mediating tools: iPads and textbooks (Engestrom 1999). The subject, object and tool are observed within the context of a teaching-learning process, in which activity is embedded. In the Activity Theory triangle the control of learning is iPad based vs textbook based tasks, and the communication of learning is interactive vs traditional learning environment. In this section of reflective journal analysis of the study these six elements comprise and govern the activity system. This practical view of the activity with emphasis on the mediating tools makes the activity theory well suited for the analysis of process and activities involving significant components in higher education (Khanova 2012).

"An action is a discrete element of activity that fulfills an intermediate, conscious goal of activity" (Bedny and Harris 2009, p. 132). Hence, the actions leading to realize a task result in the achievement of the goal. Taking this into consideration the subcategories of the conceptual AT triangles illustrated in Figure 1 were looked at in loops to discuss the reflective journals in depth and find out results of actions in relation to the goal. 


\section{Phase one: Reflective journals in two iPad groups}

The Teacher A's (iPad group 1) and Teacher B's (iPad group 2) reflections have many similarities about advantages and disadvantages of using iPads as a means of language learning. Both teachers wrote about technical glitches and variouse issues with operating iPads for the first class mainly. "Students had some issues with operating the programs and needed constant assistance", "Technical issues wasted almost one teaching period", "There were students who struggled to write or read on the tablet screen" (Teacher A). "Though we had couple of technical glitches with iPad apps and e-book codes, we successfully went through the first week", "They were not quite happy and willing to work on iPads", "Students got irritated when writing on the screen because the space for writing was too small" (Teacher B). As can be seen from the above mentioned journal entries, students expressed resistance to applying the new method for learning during the first week. However, there is no evidence of further complaints or resistance from the second week onwards in any of the teachers' reflections.

Besides technical glitches there were also positive effects of using iPads for language achievement. Both teachers mentioned that their students easily and quickly started using the technology. "I was impressed with the mini projects that pairs quickly and easily produced through the iMovie", "They easily and quickly completed all reading exercises", "Students got handy with the iPads and completed operations with ease", "They drew on their answers from previouse activities and quickly referred back to their e-notes from previous units", "This week students individually put their traditional food recipes on blogs, podcasts, and PhotoStories online" (Teacher A). "This week I noticed my students were growing up tech-savvy and mastering their collaborative working skills", "They were easily searching for new information and figuring out how to use it for their advantage and to share with eachother" (Teacher B). These reflections indicate that iPads allow students to deal with course content easily and productively, which may not be possible with other educational tools. It promotes creativity and hands-on learning. It is obviouse that students can search for new vocabulary with a single click or refer to their previouse notes in seconds and not lose precious minutes of class time. Learners prefer receiving information quickly from multiple multimedia sources and to network simultaniousely with their peers. Teacher reflections on ease of iPad use show that it enables collaborative interaction between students emphasising its influence on the students' learning practice, and consequently on their language performance and achievement.

Throughout the journal entries the teachers mentioned about language learning being promoted through student motivation which encouraged their language learning. "It was an intensive and fun learning week for my students", "Everybody seemed to be motivated and willing to try various interactive functions for their learning. For example, one of the students suddenly exclaimed "Miss, it said well done to me" (Teacher A). "One of the tasks they enjoyed doing was the iMovie project which they did in pairs", "They liked working with the 
interactive textbook", "Students did their best to come up with impressive in-class presentations", "They liked the expansion activity a lot on page 36", "The week went very well. Students worked with their iPads at all times and enjoyed conducting their studies on them" (Teacher B).

The positive teacher reports showed that iPads initiated, guided and maintained goaloriented behaviours. Students realized that simply having the desire to accomplish the language tasks was not enough. Accomplishing those tasks required the ability and willingness to try and persist through technical obstacles and keep discovering and practicing in spite of anticipated and unanticipated iPad related challenges. A vivid example of this is Teacher A's reflection of the first week, where she writes, "Not only the unit vocabulary and grammar were mostly used accurately, the mood and motivation apparently took over the hard work." She continued then and concluded her reflection with the following words, "On this note I will say I have a strong feeling that students have made friends with iPads and found it challenging but rewarding to work with iPads to achieve their goal." Both teacher reflections indicate that students were self-determined and intrinsically motivated.

Self-regulation, which supposes students' level of independent interaction with the device, recorded a high jump in teachers' reflections throughout the teaching and learning process. "Students not only completed all the grammar exercises in the e-books independently but also practiced this grammar and vocabulary through the Tense Buster and other apps that they downloaded during weeks one and two", "When finished earlier than others, some students would try to operate new language apps, practice the language through different educational programs they found in the app-store and find new ways and answers to the questions they had" (Teacher A). "The student then insisted and suggested to explore the settings, options and consider doing a dry run with the peers to iron out the kinks", "The highlight of the week was the new language app one of the students found and shared with all of us", "It took some time, but we all followed her advice and the app turned out to be a valuable one for everyday vocabulary practice", "I noticed that when making a mistake most of the students checked the feedback and redid those items several times until they were successful" (Teacher B).

Students' newly developed skills and willingness to operate iPads for their language learning could not take them anywhere else but to satisfaction in their learning in terms of perceived tool satisfaction and usefulness. "The exercise enabled them to stop the audio at any point they wanted to, to take notes or listen again for correct pronunciation" (Teacher A). "I found that students felt more comfortable sharing their ideas and producing their work through iPads, and even the students who typically were shy or didn't have many friends in class felt like they could fit in" (Teacher B). Not only were the students satisfied with their learning ways and procedures, but also the teachers. An example of teacher satisfaction was found in Teacher A's reflection, "Overall, I was satisfied with my students' progress 
this week, which I could follow daily through the digital grade book. It provided me with the immediate assessment of my students' progress" and "Online resources helped to address issues right away enabling me to work with my students' strengths and weaknesses and provide a more customized approach to overcome in-class unanticipated problems".

\section{Phase one: Reflective journals in two textbook groups}

The evidence from reflective journals mounted that paper books have important advantages as tools for language learning. One of the advantages mentioned in Teacher C's (Textbook group 1) journal was the immersive interface of the book. "The nondistracting book interface helped students to keep on task and sucessfully complete reading and vocabulary exercises", "Due to its spatial layout students felt confident using the book and could easily access the information they needed." Teacher D (Textbook group 2) talked positively about students' direct interaction with the book, "Students underlined and highlighted important grammatical points or vocabulary on their books and wrote up notes in the margins."

As good as they appear, textbooks do have some limitations. The teacher reflections highlighted the concept that the textbook must be used judiciously. That is to say, a productive class with textbooks needs many tools in its construction. Since, there were no electronic tools but pen and paper materials used in class, the teachers had to spend a lot of time creating and adapting extra materials for better learning and language achievement. "I had to create extra materials and adapt exercises, print, cut and prepare them for group or pair work" (Teacher C). "The book activities were not enough to practice and understand Present of be and I brought in supplementary materials every day", "Extra communicative activities brought in some variety and kept away from sticking to the textbook which drove the classroom atmosphere to a final fadeout" (Teacher D).

Both teachers' reflective journals spoke about external factors hindering students' intrinsic motivation, such as constant dependence on the teacher for individual feedback, verbal communication and information sharing, no choice and variety of materials for skills and language development. "I felt classes were dull for the students as they complained about not having interesting exercises in the book", "... some students needed constant reassurance that what they did was correct and that they were going in the right direction. So they needed immediate teacher feedback to keep them moving all the time. I guess this will be an issue for coming weeks too", "I was kept on my toes by 20 students who sought individual feedback on vocabulary and grammar as they finished their exercises" (Teacher C). "This week I became aware of my students' strong and weak points and was needed every single minute to give verbal and written feedback to individual students as well as to groups of them", "I noticed students piling up at my desk after classes (especially the struggling students who hardly participate in class) at break times and waiting for me to 
look at their work and give extra help", "I was constantly needed for face-to-face feedback almost after every exercise, but I was equally able to work with individual students without losing sight of entire class" (Teacher D).

Reflective journals emphasized a connection between the book based tasks and the low level of student motivation in language learning. It was explained through time constraints and level of book difficulty. "I tried to make textbook exercises more interesting for them by creating competitions and games, which took lots of effort and time", "The units were long and students hardly managed to complete them on both books", "This week I didn't have to supplement a lot, but a couple of activities to practice the present simple tense. This was due to the lack of class time for extra activities since the units were tense and completing written tasks took students long to finish", "It still took me a lot of time to create extra materials that could provide my students with suitable situations and encourage them to ultimately use the rules in real-life communication" (Teacher C). "Grammar and writing took most of the class time." "It required a considerable amount of guided student time inside the classroom to enable understanding and retention of unit content", "The time issue was still a big concern. Though I had prepared extra help for students, no extra activities were given time to" (Teacher $\mathrm{D}$ ).

\section{Phase two: Reflective journals in two iPad groups}

Figure 1 illustrates a conceptual model of AT based explanation of two phases that two groups went through. The two groups, which were exposed to the textbook method in phase one, received iPads and commenced their studies with iPads in phase two. Therefore, the control of learning in those two groups was using no other methods or tasks but iPad based ones.

Like phase one iPad groups, phase two iPad groups experienced technical challenges for the first part of the week too. Teacher $C$ and Teacher $D$ recorded technical issues related to installations and program set-ups. "Sunday's classes were spent on installing the needed apps and e-textbooks, as well as solving technical glitches with set-ups and e-mail accounts", "Students were very slow in operating their tablets because it was a new experience for them", "It was a transition for this class from paper based to iPad based learning, therefore, some of the students took longer to adjust" (Teacher C). "My students were happy to be given a chance to study with iPads. Though they had to set up the iPads, update the programs, create apple ID and password, open e-mails, download college apps and e-books, they did their best to cooperate and patiently wait for their turn", "There were also negative reactions this week. A student was really upset when she accidentally deleted her work that she had spent considerable time creating. I tried to recover it but was not successful", "Another problem was related to iPad apps and two students didn't have credit cards to purchase those apps and had to use the free ones which didn't have all the 
functions. They weren't happy about that", "The first two days we spent on adjusting technical hiccups, but we eventually managed to create a positive atmosphere and commenced with teaching - learning" (Teacher D).

Examples of this transition were reflected through both teachers' journals throughout the experiment. "I observed enthusiasm and motivation in class which I think was connected with new tablets and innovation", "Students were keen on using their iPads for creating, completing and presenting the assigned activities. They loved the idea of experimenting, competing and sharing with peers", "Students were eager to embrace iPads and were able to troubleshoot technical issues and resolve them as quickly as possible" (Teacher C). "I felt through the use of iPads students became more fascinated with their learning compared to the phase when they used paper" (Teacher D).

While in phase one reflective journals emphasized a connection between the book based tasks and a low level of student motivation in language learning, they highlighted higher level of motivation in phase two. Time constraints and the level of book difficulty were not problems to be concerned with while using iPads, since quick e-book task completions, the variety of online extra activities and immediate electronic help and feedback were all there for students to experience and benefit. "We used a variety of digital materials, including: the e-textbooks, annotation apps, Bblearn, audio player and recording apps, as well as online educational short videos which were used to reinforce the learning acquired through previous activities and harmonize with the lesson objectives", "They didn't have to call me for feedback that often because they immediately received that feedback from their e-book and used the time purposefully to redo the exercises in case of mistakes", "Throughout the week my students took advantage of vast opportunities that were available to them as learners which naturally made their learning into fun" (Teacher C). "We took on this challenging week together and my students were able to show me the other side of their learning through their active participation. I have a feeling it's going to be fun learning for this group. I look forward to observing the journey unfold from this first week", "So, they practiced writing a paragraph about their favourite room and added pictures and labels where necessary. Then through mirroring students shared their paragraphs with others and voted for the best", "There is no doubt that iPad based delivery in particular and interactive learning in general, brought the language achievement and motivation of this group to a whole new level" (Teacher D).

In the loop of interactive learning environment both phases showed quite a high level of student motivation and language achievement. "They created a social reading experience through Bblearn group discussion board, which allowed them to connect with students reading the same text, ask questions, make comments, read their peers' comments, express opinions and provide an interactive experience", "With the help of e-book exercises and support apps students seemed to understand better and practice the new grammar", "I felt the use of iPads in language class has greatly encouraged confidence and risk taking 
among my students" (Teacher C). "After completing several activities with Tense-Buster app students mastered this grammar and successfully used it in writing sentences and making notes in the charts given on page 74", "Judging from their active participation in class, one could say that there was evidence of constructive student-student, iPad-student, as well as teacher-student rapport", "... it resulted in instant feedback, variety of ways to accommodate different learning styles, developing cooperative, communicative skills and self-confidence when given a chance to redo the same task many times until they are successful and be praised for it", "Never before has it been so easy and enjoyable to put together and share content with each other" (Teacher D).

The activity of learning through textbooks as compared to the activity of learning through iPads, which was undertaken by the same subjects throughout two phases to achieve the same object, transformed it into an outcome in both phases and demonstrated positive results regardless of textbook related or technological challenges. The 24 reflective journals showed that iPad based learning carries more benefits than textbook based learning in terms of motivation and learning effectiveness. The table summarizes the positive and negative teacher reflections of each method registered in reflective journals throughout the two phases of the experiment.

\section{Discussion}

The language achievement is easier, faster and more enjoyable when iPads are used as a means of learning. The level one language learners experienced the digital world for learning the target language that was completely out of sync with traditional approaches and assumptions about teaching, learning, giving feedback or assessing. Despite the best of intentions to teach the language through traditional methods, the textbook based teaching and learning did not really connect with modern language learners primarily because the traditional methods were targeted at learners from another age. As reflected in the journals, the students wanted their learning to be relevant, fast, applicable and instantly useful. Which is more, they wanted to know the possible relevance that learning specific language aspects have for them and their world and why it could not be fun most of the time. "While some experts may argue that the experiences the digital generation have are worthless and that play and games are simply preparation for work and life after school, for today's digital generation, play is work, and work is increasingly seen in terms of games and game play" (Jukes, McCain and Crockett 2010, p. 41).

Another interesting point raised in the journals was the constant complain of the textbook group students about not receiving immediate feedback to the completed work and teachers not being able to give enough of the class time to give individual feedback to students after every language task. The clue here is that the digital world presents the students with a direct tie between the effort taken and the reward received, whereas, the 
feedback or the reward given by the teachers in the traditional classroom during the experiment was either too nebulous or too slow to motivate students to keep the pace of progressive learning. It must be mentioned that unlike the textbook groups, iPad groups had no issues connected with the pace of receiving feedback or waiting for their work to be checked. As Jukes, McCain and Crockett (2010) mention, "A direct connection between effort and reward, immediate or deferred, is why digital culture resonates so strongly with the digital generation. In terms of immediate rewards, digital culture provides them with exactly what they not only want, but what they need most_ positive feedback" (p. 40).

To sum up, the critical point here was that students had an array of tools, options and services at their hands that gave them easy access to information they needed to achieve learning. The students in this study proved themselves digitally wise, which as Prensky (2012) defines is the ability to find practical, creative, contextually appropriate, and emotionally satisfying solutions to accomplish tasks. "Those with digital wisdom look for the cases where technology enhances thinking and understanding ... and make careful judgments about what digital enhancements are appropriate and when ... they investigate and evaluate the positive as well as negatives of new digital tools and figure out how to strike the balance that turns tools into wisdom enhancers" (Thomas 2011, p.131).

\section{Recommendations}

Though this study managed to show that it is not only enjoyable, quick and easier but also more productive to use mobile technology and particularly iPads in language learning, it did not widen the scope to look at different levels of English proficiency. Therefore, a further study could concentrate on higher levels of English proficiency paperless classrooms and compare iPad based learning with other traditional methods.

This study concentrated on Emirati female students only. Hence, it would be interesting to investigate the ways that integration of tablet technology can change the learning outcomes and attitudes of other nationality second language learners' English proficiency. Which is more, it would be interesting to see if gender plays a significant role in studying with mobile devices or not. Moreover, it would be productive to experiment with iPad related specific tasks and applications to see which exact language tasks, practices and skills can boost higher language achievement.

The results of this study suggest considerable potential for iPads to facilitate students' motivation in language learning. However, this study did not follow the aim of looking into specific ways of doing it. Another study could look into ways of student and teacher collaboration, peer-to-peer interaction and engagement in language learning by the help of iPads and offer new insights into how iPad technology or similar devices can be incorporated into learning and what specific activities can boost student motivation and learning. In addition, it would be a major contribution to the field of the English language 
teaching to look at different ways of using mobile devices other than iPads to detect beneficial ways, attitudes and practices of using those devices in the paperless language classroom.

\section{Limitations}

There were anticipated and unanticipated limitations to this study, but, where possible, steps were taken to control or prevent them. Though the students were randomly selected, by coincidence there were groups which had students with special needs. To control this limitation, simple main effect analysis was run to determine the mean difference between groups of students who scored at high, average, and low levels on the pre-test.

Another limitation was out of class iPad use. Since this study was based on in-class teaching and learning process, it did not consider out of class iPad use. However, this was a limitation that could only be partially controlled by simply banning the language apps planned for in-class use from out of class use through the Guided Access code control. By setting those codes on students' iPads teachers stopped students from using their iPads for language learning unless the codes were changed. Another limitation that was anticipated was the communication and information exchange between the students during the breaks. Since all four groups under experiment were in the same college and students shared the same eating and resting areas, they met and communicated. To partially control this limitation, students were informed about the experiment, asked to assist in conducting it and signed a consent form.

\section{Conclusion}

To truly understand the positive effects of iPad based language learning, it is crucial that language teachers fully realize the great many important changes that have taken place in the students who exhibit such a strong desire and need to use mobile devices. Digital technology has been an essential part of the students' lives since birth, and a significant consequence is that they reason and process information in ways fundamentally different from their teachers, who grew up in a much more analog world. In this second generation of mobile technology use the importance is given to using mobile devices to renovate the teaching and learning process. iPads enable language learners to learn in ways not previously possible. Effective integration of iPads is achieved when language learners are able to select applications to help them obtain information in a timely manner, analyse and synthesize the information, as well as present it creatively. As this study managed to highlight, today's "digital natives", who were level one Emirati language learners, demonstrated a strong preference and motivation for using mobile technology for their 
everyday language learning. Hence, "It is from the interaction of the human mind and digital technology that the digitally wise person is coming to be" (Prensky 2012, p. 213).

\section{References}

Bandura, A. (1999). Self-efficacy in Changing Societies. New York: Cambridge University Press.

Bandura, A. (2002). Social Cognitive Theory in Cultural Context. Applied Psychology: An International Review. Vol. 51 (2), pp. 269-290.

Barab, S. A., Evans, M. A. and Baek, E. (2004). Chapter 9: Activity Theory as a Lens for Characterizing the Participatory Unit. Handbook of Research on Educational Communications and Technology. Taylor and Francis

Bedny, G. Z. and Harris, S. R. (2009). The Systemic-Structural Theory of Activity: Applications to the Study of Human Work. Mind, Culture, and Activity. Vol. 12 (2), pp. 128-147.

Boczkowski, P., J. (2010). The Mutual Shaping of Technology and Society in Videotex Newspapers: Beyond the Diffusion and Social Shaping Perspectives. The Information Society. Vol. 20 (2), pp. 225-267.

Bryman, A. and Bell, E. (2007). Business Research Methods. London: Oxford University Press.

Cheung, R. and Vogel, D. (2013). Predicting user acceptance of collaborative technologies: An extension of the technology acceptance model for e-learning. Computers and Education. Vol. 63 (1), pp. 160-175.

Chiu, C., Hsu, M. and Wang, E. Understanding knowledge sharing in virtual communities: An integration of social capital and social cognitive theories. Science Direct. Vol. 42 (1), pp. 1872-1888.

Churchill, D. and Wang, T. (2014). Teacher's use of iPads in Higher Education. Educational Media International. Vol. 51 (3), pp. 214-225.

Cooke, R. and French, D. P. (2008). How well do the theory of reasoned action and theory of planned behaviour predict intentions and attendance at screening programs? A meta-analysis. Psychology and Health. ISSN: 0887-0446 (Print) 1476-8321 (Online) Journal homepage: http://www.tandfonline.com/loi/gpsh20. Routledge, Taylor and Francis Group.

Doane, A. N., Pearson, M. R. and Kelley, M. L. (2014). Predictors of cyberbullying perpetration among college students: An application of the Theory of Reasoned Action. Computers in Human Behaviour. Vol. 36 (1), pp. 154-162.

Engestrom, Y. (1999). Perspectives on Activity Theory. Google books: Cambridge University Press Enriquez, A. (2010). Enhancing Student Performance Using Tablet Computers. College Teaching. Vol. 58 (3), pp. $77-84$.

Esch, K. and John, O. (2004). New Insights into Foreign Language Learning and Teaching. Wissenschaften: Peter Lang.

Fishbein, M. and Ajzen, I. (2010). Predicting and Changing Behaviour. The Reasoned Action Approach. New York: Taylor and Francis Group. 
Flick, U. (2006). The SAGE Dictionary of Social Research Methods. London: SAGE Publications.

Ghezzi, A., Rangone, A. and Balocco, R. (2013). Technology diffusion theory revisited: a regulation, environment, strategy, technology model for technology activation analysis of mobile ICT. Technology Analysis \& Strategic Management. Vol. 25 (10), pp. 1223-1249.

Gong, M., Xu, Y., and Yu, Y. (2004). An Enhanced Technology Acceptance Model for Web-based Learning. Journal of Information Systems Education. Vol. 15(4), pp. 365-374.

Jukes, I., McCain, T. and Crockett, L. (2010). Understanding the Digital Generation. Canada. Corwin

Khanova, J. (2012). Moving Courses Online as a Catalyst of Pedagogical Innovation: An Activity Theory Based View. School of Information and Library Science: University of North Carolina

Lai, C., Shum, M., and Tian, Y. (2014). Enhancing learners' self-directed use of technology for language learning: the effectiveness of an online training platform. Computer Assisted Language Learning. Vol. 29 (1), pp.40-60.

Liaw, S. and Huang, H. (2014). Investigating Learner Attitudes toward e-books as Learning Tools: Based on the Activity Theory Approach. Interactive Learning Environments. Vol. 10 (9), pp. 10-80.

Limayem, M., Hirt, S. G., and Cheung, C. M. K. (2007). How Habit Limits the Predictive Power of Intention: The Case of Information Systems Continuance. MIS Quarterly. Vol. 31(4), pp.705-737.

Meder, A., M. and Wegner, J., R. (2015). iPads, Mobile Technologies, and Communication Applications: A Survey of Family Wants, Needs, and Preferences. Augmentative and Alternative Communication. Vol. 31 (1), pp. 27-36.

Mishra, D., Akman, I. and Mishra, A. (2014). Theory of Reasoned Action application for Green Information Technology acceptance. Computers in Human Behaviour. Vol. 36 (1), pp. 29-40.

Nardi, B. (1996). Studying Context: A Comparison of Activity Theory, Situated Action Models and Distributed Cognition. Cambridge: MIT Press.

Prensky, M. (2001). Digital Natives, Digital Immigrants. NCB University Press. Vo. 9 (5), pp.1-6.

Prensky, M. (2010). Teaching Digital Natives: Partnering for Real Learning. Calif, Corwin: Thousand Oaks.

Prensky, M. (2012). From Digital Natives to Digital Wisdom. California: Thousand Oaks.

Robson, C. (2005). Real World Research. USA: Blackwell Publishing.

Roth, W. M., Radford, I. and LaCroix, L. (2012). Working With Cultural-Historical Activity Theory. Qualitative Social Research. Vol. 13 (2), pp. 1-15.

Solomon, G. and Schrum, L. (2007). Web 2.0: New Tools, New Schools. Washington DC: ISTE. Model: Four Longitudinal Field Studies. Management Science. Vol. 46 (2), pp.186-210.

Swearer, S. M., Wang, C., Berry, B. and Myers, Z., R. (2014). Reducing Bullying: Application of Social Cognitive Theory. Theory into Practice. Vol. 53 (1), pp. 271-277. 
Teo, T. (2009). The Impact of Subjective Norm and Facilitating Conditions on Pre-service Teachers' Attitude Toward Computer Use: A Structural Equation Modeling of an Extended Technology Acceptance Model. Educational Computing Research. Vol. 40 (1), pp. 89-109.

Thomas, M. (2011). Deconstructing Digital Natives. New York: Routledge.

Tsai, M., Chen, K., and Chien, J. (2012). The factors impact of knowledge sharing intentions: the theory of reasoned action perspective. Qual Quant. Vol. 41 (1), pp. 1479-1491.

Venkatesh, V., and Davis, F. D. (2000). A Theoretical Extension of the Technology Acceptance Yin, R., K. (2009). Case Study Research: Design and Methods. London: SAGE Inc. 